\title{
Control of gastric secretion
}

\author{
BY MICHAEL E. PARSONS \\ Biosciences Division, University of Hertfordshire, College Lane, Hatfield, \\ Hertfordshire $A L 109 A B$
}

\section{Régulation de la sécrétion gastrique}

\begin{abstract}
RÉSUMÉ
Trois principaux stimulants régulent les sécrétions de l'estomac: l'acétylcholine, relarguée à partir des nerfs parasympathiques du vagus, la gastrine, relarguée à partir des cellules $\mathbf{G}$ de l'antrum du pylore de l'estomac, et l'histamine relarguée à partir de cellules contenues dans la muqueuse du fond. Pour tous ces trois sécrétagogues des récepteurs ont été identifiés sur la membrane basolatérale de la cellule partiétale. Les interrelations entre ces sécrétagogues ont été beaucoup mieux comprises avec la découverte des antagonistes sélectifs des récepteurs de l'histamine $\mathrm{H}_{2}$, dont on a trouvé qu'ils inhibaient virtuellement tous les types de sécrétions, et établissaient clairement un rôle physiologique central pour l'histamine dans la régulation de la sécrétion acide. Cette régulation est complexe, impliquant une action directe des sécrétagogues sur la cellule pariétale, et pour la gastrine et l'acétylcholine une action indirecte en relargant de l'histamine de ses réserves.

Lorsque les stimulants activent les récepteurs de la cellule pariétale, cela entraîne des modifications dans les seconds messagers qui, à leur tour, déterminent l'activité de $l^{\prime} \mathrm{H}^{+} / \mathrm{K}^{+}$ATPase (EC 3.6.1.36; la pompe à protons) situé dans le canalicule sécrétoire de la cellule qui est l'étape finale dans la production d'acide chlorhydrique par l'estomac. Des inhibiteurs sélectifs de $\mathrm{l}^{\prime} \mathrm{H}^{+} / \mathrm{K}^{+}$ATPase se sont développés, certains d'entre eux inactivent la pompe de façon irrévisible, et d'autres sont facilement réversibles. Ces composés nous ont permis de mieux comprendre las structure et la fonction de la pompe.

Les antagonistes des récepteurs de l'histamine $\mathrm{H}_{2}$ aussi bien que les inhibiteurs de la pompe à protons, se sont révélés être par leur activité antisécrétoire des agents efficaces dans le traitement des maladies en relation avec l'acidité comme l'ulcer peptique et le reflux gastro-oesophagien.
\end{abstract}

The main function of the stomach is to commence the process of food digestion. To this end the stomach secretes acid and a number of digestive enzymes, in particular, pepsin (EC 3.4.23.1). The control of gastric secretion has been the subject of intensive physiological investigation since the beginning of the century and by the mid 1960 s the key elements were in place. However, many controversies still existed, not least being the inter-relationships between the known secretory stimulants and, as will be seen, it required the intervention of the pharmacologists to unravel the problems.

\section{THE PHYSIOLOGICAL CONTROL OF GASTRIC SECRETION}

Historically the physiological control of gastric secretion has been divided into three 
phases, cephalic, gastric and intestinal, but it is now clear that these phases overlap. The cephalic phase involves stimulation of secretion via the central nervous system as a consequence of the sight, smell and taste of food and is mediated via the parasympathetic vagus nerves. With the arrival of food in the stomach the gastric phase begins and gastric secretion is stimulated by neural reflex actions and liberation of the hormone gastrin from the $\mathrm{G}$ cells of the pyloric antrum. Both vago-vagal and local reflexes are stimulated by mechanical distension of the stomach by the ingested food acting on tension receptors in the muscle layer of the stomach wall. The release of gastrin can be stimulated via the vagus nerves, but also by chemical stimulation through the breakdown products of the ingested food, particularly certain amino acids. The release of gastrin is suppressed when the $\mathrm{pH}$ of the contents falls below about $\mathrm{pH} 2 \cdot 5$. This negative feedback mechanism is believed to be primarily a consequence of the release of somatostatin from the $D$ cells which inhibits gastrin release from the adjacent $G$ cells, although a direct effect of acid on the $G$ cells themselves is not excluded. The intestinal phase of the control of gastric secretion is mainly inhibitory, mediated by both neural and humoral pathways such as the release of gastric inhibitory peptide (GIP).

\section{GASTRIC SECRETORY STIMULANTS}

From the preceding discussion it can be seen that two body chemicals can be identified as acid secretory stimulants, acetylcholine released from the parasympathetic vagal nerves and gastrin from the $\mathrm{G}$ cells of the pyloric antrum. However, it has been known for many years that a third substance naturally occurring in the body; i.e. histamine, is also a potent stimulant of acid secretion. Histamine is found in virtually every tissue and is located in the stomach in the enterochromaffin-like (ECL) cells in rodents and in mast-like cells in other species including man. Using radio-ligand-binding techniques, receptors for all three secretagogues have been identified on the basolateral membrane of the acid-secreting parietal cell, but until 1972 their physiological inter-relationship remained unresolved. Indeed, some eminent gastroenterologists were of the opinion that the ability of histamine to stimulate gastric acid secretion represented a pharmacological phenomenon and had nothing to do with normal physiology (Johnson, 1971). However, others had placed histamine in a central physiological role, suggesting that the amine was the final common mediator of acid secretion, i.e. gastrin and acetylcholine acted via mobilization of endogenous histamine from its mucosal stores (Code, 1956, 1965).

One of the problems was that adequate analytical tools did not exist to address these questions. Although non-selective anti-cholinergic drugs such as atropine could block the cholinergic receptor on the parietal cell and inhibit both vagal and acetylcholinestimulated gastric acid secretion, similar antagonists did not exist for the histamine and gastrin receptor.

\section{THE HISTAMINE $\mathrm{H}_{2}$-RECEPTOR}

The ability of histamine to stimulate gastric acid secretion was first described by Popielski (1920). Subsequently, potent and specific drugs were developed to block some of the actions of histamine, on smooth muscle for example, but without exception they failed to inhibit histamine-stimulated acid secretion. Other actions of histamine, for example the positive chronotropic effect of histamine on the heart, were also found to be refractory to 
inhibition by the classical anti-histaminic drugs, and as early as 1948 it was speculated that two populations of histamine receptor may exist (Folkow et al. 1948).

In 1964 research commenced at the laboratories of Smith Kline and French (Welwyn Garden City, Herts.) to address the question of possible histamine receptor heterogeneity. It was demonstrated that relatively minor modifications of the histamine molecule led to compounds showing relative agonist selectivity depending on the tissue studied. For example, 4-methyl histamine had only $0.2 \%$ of the agonist activity of histamine in contracting the guinea-pig ileum (a tissue containing receptors blocked by the classical anti-histamines), but retained $40 \%$ of the activity of histamine in stimulating the heart or as a stimulant of gastric acid secretion.

Further structural modification led to a series of partial agonists and weak antagonists at the hypothetical second histamine receptor, and culminated in 1972 in the publication of a paper in Nature (Black et al. 1972) defining a second class of histamine receptor (designated the $\mathrm{H}_{2}$-receptor). The paper also described the properties of a relatively specific and competitive antagonist of this receptor, burimamide. Subsequently two more potent $\mathrm{H}_{2}$ antagonists, metiamide and cimetidine, were developed. All three compounds were demonstrated to be selective and competitive antagonists at the $\mathrm{H}_{2}$-receptor on non-gastric tissues such as the heart and uterus and to inhibit histamine-stimulated gastric acid secretion in a wide variety of species, including man, indicating the involvement of $\mathrm{H}_{2}$-receptors in this response.

\section{THE CENTRAL ROLE FOR HISTAMINE IN THE PHYSIOLOGICAL CONTROL OF ACID SECRETION}

It was demonstrated at an early stage that $\mathrm{H}_{2}$ antagonists were effective inhibitors of gastrin (or pentagastrin)-stimulated gastric acid secretion, both in experimental animals (Black et al. 1972) and in man (Aadland \& Berstad, 1978), with potencies similar to those obtained against histamine. The markedly different chemical structures of the two secretagogues, together with cimetidine's established selectivity at $\mathrm{H}_{2}$-receptors on non-gastric tissue, render it unlikely that they are both acting directly on $\mathrm{H}_{2}$-receptors in the gastric mucosa. Hence, the data could be seen to support the hypothesis that gastrin acts via a mobilization of endogenous mucosal histamine. Histamine $\mathrm{H}_{2}$-receptor antagonists can also inhibit the effects of the third major secretagogue, acetylcholine, although under certain experimental circumstances cholinergically-evoked secretion does tend to be more resistant to $\mathrm{H}_{2}$-antagonist inhibition than that evoked by the other secretagogues (Black, 1973).

Since 1972 numerous studies have demonstrated that histamine $\mathrm{H}_{2}$-receptor antagonists can inhibit the effects of virtually all acid-secretory stimulants in both experimental animals and man. Acid secretion in response to the more physiological stimulus of food is inhibited and in manner quantitatively similar to that obtained against pentagastrin (Parsons, 1989), which is a predictable result since, as noted previously, food stimulates secretion in part at least by the release of endogenous gastrin.

In man gastric acid secretion resulting from central activation of the vagus nerve by either 2-deoxyglucose or insulin (Carter et al. 1976), or by sham feeding (Schoon \& Olbe, 1978), is also inhibited by $\mathrm{H}_{2}$ antagonists. Basal acid secretion in the rat, which is predominantly under vagal control, can be markedly inhibited by $\mathrm{H}_{2}$ antagonists (Parsons, 1977), as can daytime and nocturnal basal secretion in man (Longstreth et al. 
1976). Thus, a central role for histamine in the physiological control of gastric acid secretion is clearly established.

\section{PARIETAL CELL RECEPTORS}

The fact that cholinergically-evoked secretion was relatively refractory to $\mathrm{H}_{2}$-antagonist inhibition suggested that the 'histamine as the final common mediator' hypothesis was oversimplistic. Early evidence was obtained using in vitro whole-stomach, gastric mucosal or parietal-cell preparations, which indicated that there were both acetylcholine and gastrin receptors on the mucosa, which when activated led to acid secretory responses refractory to $\mathrm{H}_{2}$ antagonism (for example, see Bunce et al. 1976; Soll, 1978a). Subsequently binding studies using gastrin labelled with ${ }^{125} \mathrm{I}$ and $\left[{ }^{15} \mathrm{~N}\right] \mathrm{leucine}$ (Soll et al. 1984) confirmed the existence of these receptors on parietal cells. More recently using polymerase-chain-reaction (PCR) techniques the muscarinic acetylcholine receptor expressed on the parietal cell has been found to be of the $\mathrm{M}_{3}$ subtype (Kajimura et al. 1992). Expression cloning and characterization of the canine parietal-cell gastrin receptor has also been achieved (Kopin et al. 1992). Thus, receptors for all three main secretagogues occur on the parietal cell. There also appear to be receptors on the parietal cell for the acid-secretory inhibitory agents prostaglandin, epidermal growth factor and somatostatin (for review, see Hirschowitz et al. 1995).

\section{THE HISTAMINE-CONTAINING CELLS OF THE GASTRIC MUCOSA}

Histamine is stored within the fundic mucosa in close proximity to the parietal cell. The actual storage cells involved appear to be species-dependent, being the ECL cell in the rat but a mast-like cell in the dog and man. The ECL cell from the rat has received the most attention, but it is probable that the derived data can be extrapolated to other species. The ECL cell has a high concentration of histidine decarboxylase (EC 4.1.1.22) which is necessary for the synthesis of histamine (Dimaline \& Sandvik, 1991).

As noted earlier, the ability of the $\mathrm{H}_{2}$ antagonists to block some, if not all, the effects of vagal stimulation, acetylcholine, food and gastrin would suggest that most of the action of these agents is via release of histamine from the ECL cell. Recently, using isolated rat ECL cells of 75-95\% purity, it has been demonstrated that they do release histamine in response to gastrin, cholecystokinin (CCK) and acetylcholine, and the receptors on the cell are of the $\mathrm{CCK}_{\mathrm{B}}$ subtype and probably the muscarinic $\mathrm{M}_{1}$-receptor (Prinz et al. 1993).

Thus, the overall control of gastric acid secretion is complex, involving agonists acting at receptors on both the histamine-containing cell and the parietal cell itself. This in itself can account, for example, for the partial resistance of cholinergically-evoked secretion to the $\mathrm{H}_{2}$ antagonists, since it can stimulate acid secretion by acting on the parietal cell directly.

An additional phenomenon which has been put forward to explain the ability of $\mathrm{H}_{2}$ antagonists to inhibit the response to other secretagogues is that of potentiating interactions. Thus, for gastrin and acetylcholine to exert their full effects the histamine $\mathrm{H}_{2}$-receptor must be occupied. This hypothesis was first put forward by Grossman \& Konturek (1974) and found experimental support in the work of Soll (1978b) using canine oxyntic cell preparations. Removal of the obligatory potentiating action of 
histamine by an $\mathrm{H}_{2}$ antagonist would lead to inhibition of the response to other secretagogues. This hypothesis is clearly in conflict with the common mediator hypothesis and led to a long-lasting debate elegantly summarized by Black \& Shankley (1987). It now seems likely that both histamine release and a direct action at the parietal cell receptors underlies the actions of gastrin and acetylcholine. Whatever the complexities, the binding of the ligands to the receptors on the basolateral membrane of the parietal cell generates changes in second messengers, which then determine the activity of the gastric proton pump, the $\mathrm{H}^{+} / \mathrm{K}^{+}$-transporting ATPase (EC 3.6.1.36).

\section{CONTROL OF ACID SECRETION AT THE APICAL MEMBRANE}

By comparison with the complex control mechanisms that occur at the basolateral membrane of the parietal cell, that at the apical membrane is relatively straightforward, if not exactly simple. The $\mathrm{pH}$ of gastric juice is approximately 1.0 and that of the plasma is about $7 \cdot 0$. Thus, there is a $\mathrm{H}^{+}$gradient of approximately one million-fold. The ionic pump that produces the primary transport event is a $\mathrm{K}^{+}$-stimulated, ATP-hydrolysing, membrane-bound enzyme, the $\mathrm{H}^{+} / \mathrm{K}^{+}$-transporting ATPase, which was first described in 1973 (Ganser \& Forte, 1973). The $\mathrm{H}^{+} / \mathrm{K}^{+}$-transporting ATPase utilized ATP to catalyse the transmembrane exchange of $\mathrm{H}^{+}$from cell to lumen and $\mathrm{K}^{+}$from lumen to cell. The enzyme is an $\alpha \beta$ heterodimer present in the cytoplasmic membrane vesicles of the resting cell and in the canaliculus of the stimulated cell. The structure and biochemistry of the proton pump have been the subject of numerous reviews (for example, Forte et al. 1989; Hirschowitz et al. 1995) and are not detailed here. However, the identification of the $\mathrm{H}^{+} / \mathrm{K}^{+}$-transporting ATPase as the final step in the production of acid by the stomach provided a novel target for pharmacological intervention.

\section{THE $\mathrm{H}^{+} / \mathrm{K}^{+}$-TRANSPORTING ATPase INHIBITORS}

Inhibition of the final step of acid secretion would be the most effective way of controlling the acidity of the gastric contents and, therefore, should provide the most effective therapy for acid-related diseases such as peptic ulcer and gastro-oesophageal reflux disease. In the early $1980 \mathrm{~s}$ a series of substituted benzimidazoles, in particular omeprazole, were shown to inhibit gastric acid secretion by blocking the gastric $\mathrm{H}^{+} / \mathrm{K}^{+}$-transporting ATPase (Fellenius et al. 1981). Chemically these compounds are weak bases that will be protonated and trapped in the acidic compartment of the parietal cell. They also act as drug precursors, having to undergo an acid-catalysed conversion to a reactive product, a cationic sulphenamide, that reacts with cysteines present in the $\alpha$ subunit of the $\mathrm{H}^{+} / \mathrm{K}^{+}$-transporting ATPase (for review, see Hirschowitz et al. 1995). The reaction is covalent in nature and the pump is inactivated; for secretion to return new pump protein has to be synthesized. Thus, compounds of this class are highly effective and long-lasting inhibitors of acid secretion and have proved to be valuable therapeutic agents.

As a result of the initial concerns about the possible pathological consequences of profound and long-term inhibition of acid secretion, a second class of $\mathrm{H}^{+} / \mathrm{K}^{+}$transporting ATPase inhibitor has been researched, the so-called reversible protonpump inhibitors. Such a compound is SK\&F 96067 which inhibits the enzyme competitively with respect to the secondary transported ion $\mathrm{K}^{+}$. It binds to a specific 
luminally-exposed region of the pump. It has a high level of intrinsic selectivity for the gastric $\mathrm{H}^{+} / \mathrm{K}^{+}$-transporting ATPase and its duration of action, which is intermediate between that of omeprazole and the $\mathrm{H}_{2}$ antagonists, is determined by its plasma half-life (for review, see Pope \& Parsons, 1993). To date none of this class of compounds has entered therapeutic trials.

\section{THERAPEUTIC APPLICATIONS OF ANTISECRETORY DRUGS}

Although we still do not understand the underlying aetiology of the peptic ulcer, gastric acid is clearly important in the development and symptomology of the disease. The reduction of gastric acid secretion has been, therefore, a therapeutic target for many years. Before 1976 this was achieved either by the use of non-selective anti-cholinergics or antacids. The alternative was surgery, which could range from total gastrectomy to highly selective vagotomy.

The discovery of the histamine $\mathrm{H}_{2}$-receptor antagonists and the demonstration that they could inhibit vitually all forms of acid secretion led to the clinical trials on cimetidine (Tagamet; Smith Kline \& French) and its eventual marketing in 1976. Cimetidine revolutionized the therapy of acid-related diseases and it was followed by other compounds of the same class, such as ranitidine and famotidine. $\mathrm{H}_{2}$ antagonists have, however, only limited value in gastro-oesophageal reflux disease (GORD), for which a very high degree of acid inhibition is necessary.

With the advent of the proton-pump inhibitors a more effective means of controlling acid secretion became available and omeprazole has found widespread use in GORD and peptic ulcer therapy. Two other compounds from this class, lansoprazole and pantoprazole, have now reached the market place.

Selective $\mathrm{CCK}_{\mathrm{B}}$ and gastrin antagonists are now available, e.g. L-365, 260 (Lotti \& Chang, 1989), but have not been tested in the clinic.

\section{CONCLUSIONS}

The physiological control of gastric secretion is fairly well understood and this understanding has been helped by the discovery of selective pharmacological tools such as the histamine $\mathrm{H}_{2}$-receptor antagonists. This in turn has led to a revolution in the treatment of acid-related diseases. In the clinical arena the recognition of the importance of the micro-organism Helicobacter pylori in the aetiology of gastro-duodenal diseases will lead to the next generation of therapeutic agents.

\section{REFERENCES}

Aadland, E. \& Berstad, A. (1978). Effect of cimetidine on pentagastrin-stimulated gastric acid and pepsin secretion before and after 6 weeks of cimetidine treatment. Scandinavian Journal of Gastroenterology 13, $193-197$.

Black, J. W. (1973). Speculation about the nature of the antagonism between metiamide and pentagastrin. In International Symposium on Histamine $\mathrm{H}_{2}$-Receptor Antagonists, pp. 219-221 [C. J. Wood and M. A. Simkins, editors]. Welwyn Garden City: R \& D Division, SK \& F Labs Ltd.

Black, J. W., Duncan, W. A. M., Durant, G. J., Ganellin, C. R. \& Parsons, M. E. (1972). Definition and antagonism of histamine $\mathrm{H}_{2}$-receptors. Nature 236, 385-390.

Black, J. W. \& Shankley, N. P. (1987). How does gastrin act to stimulate oxyntic cell secretion? Trends in Pharmacological Sciences 8, 486-490. 
Bunce, K. T., Parsons, M. E. \& Rollings, N. A. (1976). The effect of metiamide on acid secretion stimulated by gastrin, acetylcholine, and dibutyryl cyclic adenosine $3^{\prime}, 5^{\prime}$-monophosphate in the isolated whole stomach of the rat. British Journal of Pharmacology 58, 149-156.

Carter, D. C., Forrest, J. A. H., Logan, R. A., Ansell, I., Lidgard, G., Heading, R. C. \& Shearman, D. J. C. (1976). Effect of the histamine $\mathrm{H}_{2}$-receptor antagonist: cimetidine, on gastric secretion and serum gastrin during insulin infusion in man. Scandinavian Journal of Gastroenterology 11, 565-570.

Code, C. F. (1956). Histamine and gastric secretion. In Symposium on Histamine in Honor of Sir Henry Dale, pp. 189-219 [G. E. W. Wolstenholme and C. M. O'Connor, editors]. Boston: Little, Brown and Company.

Code, C. F. (1965). Histamine and gastric secretion: a later look, 1955-1965. Federation Proceedings 24, 1311-1321.

Dimaline, R. \& Sandvik, A. K. (1991). Histamine decarboxylase gene expression in rat fundus is regulated by gastrin. FEBS Letters 283, 20-22.

Fellenius, E., Berglindh, T., Sachs, G., Olbe, L., Elander, B., Sjöstrand, S. E. \& Wallmark, B. (1981). Substituted benzimidazoles inhibit gastric acid secretion by blocking $\mathrm{H}^{+} / \mathrm{K}^{+}$ATPase. Nature 290, $159-161$.

Folkow, B., Haeger, K. \& Kahlson, G. (1948). Observations on reactive hyperaemia as related to histamine, on drugs antagonising vasodilation induced by histamine and on vasodilator properties of adenosine triphosphate. Acta Physiologica Scandinavica 15, 264-278.

Forte, J. G., Hanzel, D. K. \& Urushidani, T. (1989). Mechanisms of parietal cell function. In Advances in Drug Therapy of Gastrointestinal Ulceration, pp. 33-52 [A. Garner and B. J. R. Whittle, editors]. Chichester: John Wiley and Sons.

Ganser, A. L. \& Forte, J. G. (1973). $\mathrm{K}^{+}$stimulated ATPase in purified microsomes of bullfrog oxyntic cells. Biochimica et Biophysica Acta 307, 169-180.

Grossman, M. I. \& Konturek, S. J. (1974). Inhibition of acid secretion in dog by metiamide, a histamine antagonist acting on $\mathrm{H}_{2}$-receptors. Gastroenterology 66, 517-521.

Hirschowitz, B. I., Keeling, D., Lewin, M., Okabe, S., Parsons, M., Sewing, K., Wallmark, B. \& Sachs, G. (1995). Pharmacological aspects of acid secretion. Digestive Diseases and Sciences 40, Suppl, 3s-23s.

Johnson, L. R. (1971). Control of gastric secretion: no room for histamine? Gastroenterology 61, 106-118.

Kajimura, M., Reuben, M. A. \& Sachs, G. (1992). The muscarinic receptor gene expressed in rabbit parietal cells is the $\mathrm{M}_{3}$ subtype. Gastroenterology 103, 870-875.

Kopin, A. S., Lee, Y. M., McBride, E. W., Miller, L. J., Lu, M., Lin, H. Y., Kolakowski, L. F. \& Beinborn, M. (1992). Expression cloning and characterisation of the canine parietal cell gastrin receptor. Proceedings of the National Academy of Sciences, USA 89, 3605-3609.

Longstreth, G. F., Go, V. L. W. \& Malagelada, J. R. (1976). Cimetidine suppression of nocturnal acid secretion in active duodenal ulcer. New England Journal of Medicine 194, 801-804.

Lotti, V. J. \& Chang, R. S. L. (1989). A new potent and selective non-peptide gastrin antagonist and brain cholecystokinin (CCK-B) ligand L-365,260. European Journal of Pharmacology 162, 273-281.

Parsons, M. E. (1977). The antagonism of histamine $\mathrm{H}_{2}$-receptors in vitro and in vivo with particular reference to the actions of cimetidine. In Cimetidine: Proceedings of the Second International Symposium on Histamine $\mathrm{H}_{2}$-Receptor Antagonists, pp. 13-20 [W. L. Burland and M. A. Simkins, editors]. Amsterdam and Oxford: Excerpta Medica.

Parsons, M. E. (1989). Experimental studies with histamine $\mathrm{H}_{2}$-receptor antagonists. In Advances in Drug Therapy of Gastrointestinal Ulceration, pp. 17-31 [A. Garner and B. J. R. Whittle, editors]. Chichester: John Wiley and Sons.

Pope, A. J. \& Parsons, M. E. (1993). Reversible inhibitors of the gastric $\mathrm{H}^{+} / \mathrm{K}^{+}$-transporting ATPase: a new class of antisecretory agents. Trends in Pharmacological Sciences 14, 323-325.

Popielski, L. (1920). $\beta$-Imidazolylathylamine und de organextrakt: $\beta$-Imidazolylathylamine als machtiger erreger der magendruson ( $\beta$-Imidazolylethylamine and the organ extract: $\beta$-Imidazolylethylamine is a powerful stimulant of the gastric glands). Pflugers Archives European Journal of Physiology 178, 214-226.

Prinz, C., Kajimura, M., Scott, D., Meseier, F., Helander, H. F. \& Sachs, G. (1993). Histamine secretion from enterochromaffin-like cells. Gastroenterology 105, 449-461.

Rosenfeld, G. C., Ecknauer, R., Johnson, L. R. \& Thomson, W. J. (1978). Purified gastric mucosal parietal cells: demonstration of $\left[{ }^{3} \mathrm{H}\right]$ QNB binding to cholinergic receptors. 7th International Congress of Pharmacology, Paris. 319 Abstr.

Schoon, I. M. \& Olbe, L. (1978). Inhibitory effect of cimetidine on gastric acid secretion vagally activated by physiological means in duodenal ulcer patients. Gut 19, 27-31.

Soll, A. H. (1978a). The action of secretagogues on oxygen uptake by isolated mammalian parietal cells. Journal of Clinical Investigation 61, 370-380. 
Soll, A. H. (1978b). The interaction of histamine with gastrin and carbamylcholine on oxygen uptake by isolated mammalian parietal cells. Journal of Clinical Investigation 61, 381-389.

Soll, A. H., Amerian, D. A., Thomas, L. P., Reedy, T. J. \& Elashoff, J. D. (1984). Gastrin receptors on isolated canine parietal cells. Journal of Clinical Investigation 73, 1434-1437. 